Ключові слова: умотивований студент, заохочення, іншомовна навчальна діяльність, комунікативна ситуація, методи навчання, мотивація, нагорода, стиль навчання, тімбілдинг.

\title{
PEЗЮME
}

Лобачева Ирина. Условия формирования положительной мотивации студентов к изучению иностранных языков.

В статье рассмотрен ряд способов мотивации студентов к изучению иностранного языка. Определены инструкции по эфрективному обучению английскому языку и предложены пути побуждения студентов к иноязычной учебной деятельности. Выяснено, что мотивация студентов зависит от определенных целей, насущных проблем, карьерных перспектив, поощрения, мотивов, опосредованного воздействия преподавателя и использования всего арсенала учебных средств, наиболее способствующих мотивации. Доказано, что использование различных методов, фрорм и средств организации учебной деятельности, создание благоприятных условий во время обучения английскому языку способствуют формированию положительной мотивации студентов и позволяют обеспечить эфрфективное усвоение аутентичного иноязычного материала.

Ключевые слова: мотивированный студент, поощрение, иноязычная учебная деятельность, коммуникативная ситуация, методы обучения, мотивация, награда, стиль обучения, тимбилдинг.

УДК 372.46(493)

Олена Мартиненко

Сумський державний педагогічний

університет імені А. С. Макаренка ORCID ID 0000-0002-8287-0573

Ярослав Чкана

Сумський державний педагогічний

університет імені А. С. Макаренка

ORCID ID 0000-0003-3667-3584

DOI 10.24139/2312-5993/2019.05/131-139

\section{ВИКОРИСТАННЯ ГЛОСАРІЮ ПРИ ФОРМУВАННІ ІНФОРМАЦІЙНОЇ КОМПЕТЕНТНОСТІ ІНОЗЕМНИХ СТУДЕНТІВ ПРИ НАВЧАННІ МАТЕМАТИЧНИХ ДИСЦИПЛІН У ПЕДАГОГІЧНИХ УНІВЕРСИТЕТАХ}

у статті досліджено важливі аспекти формування інформаційної компетентності іноземних студентів при навчанні математичних дисциплін у педагогічних університетах. Обгрунтовано дочільність упровадження білінгвального навчання при формуванні інформаційної компетентності іноземних студентів; описано методичні особливості використання в навчальному процесі словника математичних термінів (глосарію) як однієї з форм білінгвізму. Виділено складові інформаційної компетентності студентів фізико-математичного фракультету педагогічного університету та схарактеризовано рівні їі сформованості. 
Ключові слова: інформаційна компетентність, іноземні студенти, білінгвальне навчання, глосарій, математичні дисципліни.

Постановка проблеми. Запорукою успішного розвитку кожної країни $\epsilon$ наявність інтелектуальних кадрів, що визначає пріоритетним напрямом підготовку фахівців у галузі фізико-математичної освіти. Глобалізація сучасного суспільства обумовлює міжнародний характер освіти, її інтернаціоналізацію (Сбруєва та Козлов, 2016), що виражається в зростанні академічної мобільності студентів. Значно посилюється тенденція отримання вищої освіти за кордоном. Збільшення частки іноземних студентів спостерігається й у закладах вищої освіти України, зокрема, в педагогічних університетах.

Досвід навчання математики туркменських студентів на фізикоматематичному факультеті Сумського державного педагогічного університету імені А. С. Макаренка свідчить, що серед основних проблем переважають такі, як: слабка математична підготовка, погані знання загальновживаної математичної термінології та позначень; відсутність навичок самоосвіти, пошуку необхідної інформації (невміння працювати $з$ підручниками, задавати параметри пошуку в пошукових системах); слабка мотивація до навчання; труднощі при збереженні отриманої інформації; погане володіння українською мовою.

Ми вважаємо, що успішне навчання туркменських студентів буде зумовлюватися, насамперед, сформованістю їх інформаційної компетентності. При цьому природнім $€$ впровадження білінгвального навчання, але даний процес вимагає розв'язання низки питань, пов'язаних із його організацією, визначенням цілей, оцінкою результатів і соціальнопсихологічною адаптацією студентів. Це передбачає необхідність глибокого вивчення, подальшої розробки форм і методів білінгвального навчання та напрацювання відповідної методики викладання фахових математичних дисциплін при підготовці іноземних студентів з урахуванням наявного позитивного педагогічного досвіду.

Аналіз актуальних досліджень. В умовах швидкого та значного збільшення кількості інформаційних ресурсів одним із пріоритетних завдань сучасного інформаційного суспільства $€$ підготовка спеціаліста 3 високим рівнем сформованості інформаційної компетентності. Дослідженням цього питання займаються вчені різних країн світу, зокрема кафедра інформаційної грамотності державного університету Каліфорнії (Patti, et al.), О.Барановська, М.Головань, А. Зав'ялова, В. Недбай, О. Зайцева, А. Хуторський, Д. Єланцев та інші. 
Проблеми білінгвального навчання розглядаються як зарубіжними, так і вітчизняними науковцями в контексті підготовки фахівців різних галузей. Теоретичні основи білінгвізму знайшли відображення у працях таких науковців, як Є. Верещагіна, М. Михайлова, В. Маккея, М. Певзнера, І. Турмана, А. Ширіна. Серед досліджень щодо проблем та перспектив упровадження білінгвального навчання в освіту слід виокремити роботи М. Фарелла, Метцнера (Metzner), В. Хецин, Г. Александрової, Л. Плієвої,
3. Смирнової,
І. Білецької,
Т. Боднарчук,
І. Зозулі,
К. Ігнатенко,

С. Ситняківської,

О. Усенко,

В. Гаманюк,

Л. Бондаренко,

А. Гусака,

А. Ковальчук та ін. В Україні педагогічні дослідження білінгвальної починаються з 90-х років XX століття (Бондаренко та Чорнобай, 2018).

На думку Я. Поченюк, іноземна мова повинна бути не лише об'єктом, але й засобом навчання (Поченюк, 2012), а дослідження М. Фарелла (Farrell, 2011) підтверджують позитивний вплив білінгвізму на розвиток інтелектуальних здібностей при вивченні фізики та математики.

Однак, варто зауважити, що в сучасній педагогічній науці детально вивчені окремі аспекти білінгвальної освіти, але цілісної концепції поки що не сформовано. Подальшого дослідження потребують і питання, пов'язані 3 особливостями впровадження білінгвізму при навчанні іноземних студентів у педагогічних університетах України, зокрема, майбутніх учителів математики.

Мета статті - визначення принципів навчання математичних дисциплін та обґрунтування доцільності впровадження білінгвального навчання при формуванні інформаційної компетентності туркменських студентів у педагогічних університетах; описання методичних особливостей використання словника математичних термінів (глосарію) як однієї з форм білінгвізму в навчальному процесі.

Для досягнення поставленої мети були використані теоретичні та емпіричні методи дослідження. Теоретичні методи охоплюють аналіз науково-методичної літератури для узагальнення й систематизації результатів із проблеми дослідження; емпіричні - педагогічне спостереження за навчально-виховним процесом відповідно до проблеми дослідження, узагальнення власного педагогічного досвіду та досвіду колег з інших закладів вищої педагогічної освіти.

Виклад основного матеріалу. Сучасною тенденцією в системі вищої освіти України є збільшення контингенту іноземних студентів. Зокрема, за останні 5 років на фізико-математичному факультеті Сумського державного педагогічного університету імені А.С. Макаренка значно зросла кількість іноземних студентів - громадян Туркменістану. Особливістю організації 
навчального процесу $\epsilon$ те, що вони відразу інтегруються в академічні групи разом із українськими студентами. Це викликає певні труднощі як у навчанні самих студентів, так і в роботі викладачів. Аналіз досліджень колег та власний досвід свідчать, що розв'язання цих проблем, насамперед, пов'язане $з$ усуненням відмінностей функціонування систем шкільної та вищої педагогічної освіти України та країни, з якої приїхав студент на навчання, та підвищенням до належного наявного рівня його базової академічної підготовки і здатності до самоосвіти. Крім того, важливим є питання щодо соціально-психологічної адаптації іноземних студентів, що включає лінгвістичний, етнокультурний і фінансовий аспекти та особистісну безпеку.

Ми вважаємо, що визначальним фактором у подоланні зазначених проблем $\epsilon$, насамперед, формування інформаційної компетентності іноземних студентів - майбутніх учителів математики. Поняття інформаційної компетентності науковцями трактується по-різному. Поділяючи думки А. Хуторського (Хуторской, 2003) та Д. Єланцева (Еланцев), під інформаційною компетентністю ми будемо розуміти інтегративну якість особистості, що є результатом діяльності по відношенню до інформації $з$ різних предметних галузей, і виявляється у здатності до пошуку, аналізу та відбору необхідної інформації, її обробки, збереження та передачі.

у структурі інформаційної компетентності іноземних студентів фізико-математичного факультету педагогічного університету ми виділяємо такі складові:

- термінологічну (володіння символікою та термінологією математичних дисциплін, розуміння взаємозв'язків між ними);

- технологічну (володіння різними засобами пошуку, обробки, збереження та передачі інформації);

- навчально-організаційну (здатність до використання інформаційнокомунікаційних технологій щодо організації навчальної діяльності при вивченні математичних дисциплін).

Узагальнюючи сучасні педагогічні дослідження, виділимо такі напрями діяльності викладачів щодо формування інформаційної компетентності іноземних студентів:

- навчити ефективно працювати з інформацією при різних формах їі подання;

- розкрити технологічні можливості сучасних комп'ютерних засобів та програмного забезпечення в навчальній діяльності;

- показати різні аспекти прикладного застосування сучасних інформаційних та комп'ютерних технологій. 
У процесі навчання математичних дисциплін іноземних студентів формування інформаційної компетентності спирається на використання певного комплексу принципів, який включає принцип візуалізації інформації, принцип інваріантності математичних знань по відношенню до мови навчання, принцип повторюваності математичної термінології, принцип індивідуалізації в організації навчального процесу, принцип мотивації (Козырева и др., 2017). Відповідно до напрямів діяльності із формування інформаційної компетентності іноземних студентів, їх реалізація відбувається через упровадження білінгвального навчання, що ґрунтується на одночасному використанні державної мови та мови-партнера і враховує соціально-культурний контекст щодо комунікацій в країні отримання вищої освіти (Степанян, 2017; Боднарчук, 2013). При навчанні туркменських студентів на фізико-математичному факультеті в Сумському державному педагогічному університеті імені А. С. Макаренка такою мовою $є$ російська, що обумовлено етнокультурною специфікою країни проживання.

Математика має свою універсальну символіку, вона менше за інші науки залежить від знання мови. Тому при вивченні математичних дисциплін використання мови-партнера спрямоване, перш за все, на розуміння та засвоєння термінологічної бази, на роботу з математичними текстами, пошук необхідної інформації в різних джерелах.

Інтенсифікацію навчання математичних дисциплін іноземних студентів і формування основ їх інформаційної компетентності при білінгвальному підході забезпечує впровадження в практику спеціальних програмнопедагогічних розробок. Одним із таких методичних засобів є глосарій з математичних дисциплін. Він сприяє формуванню в кожного студента необхідної термінологічної бази, спонукає студентів-іноземців до пошуку навчальної інформації та дозволяє встановлювати свій власний темп навчання.

у глосарії мовою символів і російською подано необхідну математичну символіку з транскрипцією її читання, основні поняття та їх означення, важливі математичні твердження відповідно до розділів та робочої програми дисципліни. Але, крім предметно-змістового аспекту, при викладі матеріалу особлива увага приділена мовному і врахована лінгвістично-синтаксична складність написання тексту.

Для зручності пошуку потрібної інформації в кінці посібника наведено алфавітний покажчик термінів українською, російською, туркменською мовами. Використання саме трьох мов дозволяє іноземним студентам швидше адаптуватися та включитися в навчальний процес, де викладання ведеться українською. 
Крім того, вивченню математичних дисциплін кожним іноземним студентом, установленню комунікацій «студент-студент», «студентвикладач» та його соціалізації в даній спільноті буде значно сприяти складання персонального словника. Така робота стимулює до використання різних пошукових систем щодо перекладу, вимови та значення необхідних слів, словосполучень тощо.

Відповідно до запропонованої структури інформаційної компетентності виділяємо чотири рівні їі сформованості: низький, середній, достатній та високий. Схарактеризуємо складові сформованості інформаційної компетентності іноземних студентів педагогічного університету при вивченні математичних дисциплін (див. табл. 1).

Таблиця 1

Характеристика рівнів сформованості інформаційної компетентності іноземних студентів педагогічного університету (на прикладі фізикоматематичного факультету СумДПУ імені А. С. Макаренка)

\begin{tabular}{|c|c|}
\hline $\begin{array}{c}\text { Рівень } \\
\text { сформованості }\end{array}$ & Характеристика рівня \\
\hline Низький & $\begin{array}{l}\text { Знання математичної символіки та термінології } \epsilon \\
\text { фрагментарними й несистемними, студент на елементарному рівні } \\
\text { володіє вміннями здобувати та опрацьовувати інформацію (має } \\
\text { слабке уявлення про можливості використання ІКТ для пошуку } \\
\text { даних та їх опрацювання; знає основні прийоми роботи з } \\
\text { програмним забезпеченням загального призначення, але потребує } \\
\text { незначної сторонньої допомоги); зазнає труднощі при самостійній } \\
\text { роботі з інформацією та потребує допомоги викладача }\end{array}$ \\
\hline Середній & $\begin{array}{l}\text { Знання студента відповідають репродуктивному рівню, що } \\
\text { передбачає відтворення ним навчальної інформації, операцій, дій, } \\
\text { засвоєних у процесі навчання. Він має комплексні уявлення про } \\
\text { можливості ІІТ щодо опрацювання інформації; володіє основними } \\
\text { прийомами роботи з програмним забезпеченням загального призна- } \\
\text { чення та математичними пакетами, уміє застосовувати їх із незначною } \\
\text { сторонньою допомогою. Організація самостійної роботи студента з } \\
\text { інформацією відбувається, в основному, за заданим алгоритмом і під } \\
\text { керівництвом викладача, але іноді не досить чітко та швидко }\end{array}$ \\
\hline Достатній & $\begin{array}{l}\text { Студент має системні знання з математичних дисциплін, } \\
\text { здійснює самостійне реконструктивне їх відтворення; уміє } \\
\text { аналізувати та пояснювати не тільки результат, а й процес його } \\
\text { одержання. Він вільно володіє ІКТ для пошуку та опрацювання } \\
\text { інформації, уміє доцільно застосовувати програмне забезпечення } \\
\text { для розв'язування навчальних завдань, однак виявляє при цьому } \\
\text { деяку невпевненість при нестандартних ситуаціях. Самостійна } \\
\text { робота студента з інформацією організована на належному рівні, } \\
\text { але їй не вистачає елементів творчості }\end{array}$ \\
\hline Високий & $\begin{array}{l}\text { Знання студента з математичних дисциплін } \epsilon \text { глибокими та } \\
\text { системними, іх відтворення відбувається } 3 \text { елементами }\end{array}$ \\
\hline
\end{tabular}




\begin{tabular}{|l|l|}
\hline перетворення та кодування. Наяність дослідницького характеру \\
навчальної діяльності студента спонукає його до пошуку власного \\
способу дій при розв'язуванні поставленого завдання. Він виявляє \\
повну самостійність при виборі та застосуванні ІКт для отримання \\
об'єктивно нової інформації, володіє основними прийомами \\
роботи з програмним забезпеченням і доцільно застосовує їх має \\
навички управління інформаційною системою в нестандартних \\
ситуаціях. Студент уміє розробляти нові способи діяльності щодо \\
отримання та опрацювання інформації, він володіє вміннями \\
змінювати стратегії навчання
\end{tabular}

Для визначення рівнів сформованості інформаційної компетентності туркменських студентів при вивченні математичних дисциплін на фізикоматематичному факультеті СумДПу імені А. С. Макаренка проводилося тестування в три етапи: на початку вивчення курсу (для встановлення вихідних знань та початкового рівня), у середині курсу (для проміжної рефлексії та корекції), у кінці курсу (для вимірювання набутого рівня). Отримані результати тестування показали позитивну динаміку у формуванні їх інформаційної компетентності.

Висновки та перспективи подальших наукових пошуків. Поєднання теоретичного аналізу наукових досліджень із даного питання та власного досвіду роботи з туркменськими студентами дозволило зробити висновок, що формування інформаційної компетентності іноземних студентів у процесі навчання математичних дисциплін у педагогічних університетах $€$ комплексною проблемою. П̈ї розв'язанню сприяє вибір білінгвального навчання як ефективної форми їх фахової підготовки та соціальнопсихологічної адаптації.

На нашу думку, подальшої розробки потребують методичні аспекти впровадження різних форм і методів білінгвального навчання 3 урахуванням етнокультурних особливостей та рівня математичної підготовки іноземних студентів.

\section{ЛІТЕРАТУРА}

Сбруєва, А., Козлов, Д. (2016). Інтернаціоналізація як драйвер розвитку інноваційної системи університету. Педагогічні науки: теорія, історія, інноваційні технології, 6(60), 71-87 (Sbruieva, A., Kozlov, D. (2016). Internationalization as a driver for the development of the university innovation system. Pedagogical sciences: theory, history, innovative technologies, 6(60), 71-87).

Patti, S. Caravello, Chair, Eloisa Gomez Borah, Judith Herschman, Eleanor Mitchell. UCLA Library Information Competence at UCLA: Report of a Survey Project. Retrieved from: www.library.ucla.edu/infocompetence/index noframes.htm.

Бондаренко, Л. І., Чорнобай, К. Г. (2018). Білінгвальне навчання фізики при підготовці майбутніх фахівців у закладах вищої освіти. Фізико-математична освіта, 2 (16), 23-26 (Bondarenko, L. I., Chornobai, K. H. (2018). Bilingual teaching physics in the 
preparation of future specialists in higher education institutions. Physical and Mathematical Education, 2(16), 23-26).

Поченюк, Я. (2012). Зміст Європейських моделей білінгвальної освіти: від теорії до практики. Проблеми підготовки сучасного вчителя: збірник наукових праць Уманського державного педагогічного університету імені Павла Тичини. Умань, вип. 5, 4. 2, 245-251 (Pocheniuk, Yа. (2012). The content of European models of bilingual education: from theory to practice. Problems of preparing a modern teacher: a collection of scientific works of Uman State Pedagogical University named after Pavlo Tychyna. Uman, Issue 5, part 2, 245-251).

Farrell, M. P. (2011). Bilingual competence and students' achievement in Physics and Mathematics. International Journal of Bilingual Education and Bilingualism. 14 (3), 33-345.

Хуторской, А. В. (2003). Ключевые компетенции как компонент личностноориентированного образования. Народное образование, 2, 58-64 (Khutorskoi, A. V. (2003). Key competencies as a component of student-centered education. Public education, 2, 58-64).

Еланцев, Д. В. Модель информационной компетентности преподавателей высшей школы в условиях кредитной технологий обучения. Вестник КазНУ, 21, 92-96 (Elantsev, D. V. Model of information competence of teachers of higher school in the conditions of credit technologies of training. Bulletin of $\mathrm{KazNU}, 21,92-96)$.

Козырева, А. В., Колпакова, С. В., Бурлакова, Е. А. (2017). Особенности обучения иностранных студентов математике. Современные исследования социальных проблем, 8 (4-2), 128-133 (Kozyreva, A. V., Kolpakova, S. V., Burlakova, E. A. (2017). Peculiarities of teaching foreign students mathematics. Current research on social issues, 8 (4-2), 128-133).

Степанян, И. К., Дубинина, Г. А., Ганина, Е. И. (2017). Билингвальный подход к обучению математике иностранных студентов. Международный научноисследовательский журнал, 12 (66), 4. 1, 167-172 (Stepanian, I. K., Dubinina, H. A., Hanina, Ye. I. (2017). Bilingual approach to teaching mathematics to foreign students. International Research Journal, 12 (66), Part 1, 167-172).

Боднарчук Т. В. (2013). Особливості розвитку білінгвальної освіти у сучасній українській школі. Педагогіка. Розділ 1. Збірник наукових праць. Випуск 14, (сс. 37-42) (Bodnarchuk, T. V. (2013). Peculiarities of development of bilingual education in modern Ukrainian school. Pedagogy. Section 1. Collection of scientific works. Issue 14, (pp. 37-42).

\section{PEЗЮME}

Мартыненко Елена, Чкана Ярослав. Использование глоссария при формировании информационной компетентности иностранных студентов при изучении математических дисциплин в педагогических университетах.

В статье рассмотрены важные аспекты формирования информационной компетентности иностранных студентов при изучении математических дисциплин в педагогических университетах. Обоснована целесообразность использования билингвального обучения при фрормировании информационной компетентности иностранных студентов; дано описание методических особенностей использования в учебном прочессе словаря математических терминов (глоссария) как одной из форм билингвизма. Выделены компоненты информационной компетентности студентов физико-математического фокультета педагогического университета и охарактеризованы уровни ее срормированности. 
Ключевые слова: информационная компетентность, иностранные студенты, билингвальное обучение, глоссарий, математические дисциплины.

\section{SUMMARY}

Martynenko Olena, Chkana Yaroslav. Use of a glossary in the formation of information competence of foreign students in teaching of mathematical disciplines in pedagogical universities.

The growth of academic mobility of students is a characteristic trend of contemporary society, which is conditioned by the international character of education. An increase in the share of foreign students is also observed in pedagogical universities of Ukraine.

The experience of teaching mathematics of Turkmen students at the Faculty of Physics and Mathematics of Sumy State Pedagogical University named after A. S. Makarenko suggests that there is a number of problems related to their mathematical training, ethnocultural features and adaptation in a foreign-speaking society. We believe that in this context, it is important to work on the formation of the informational competence of foreign students. Under the informational competence we will understand the integrative quality of the individual, which is the result of activities in relation to information from various subject areas, and manifests itself in the ability to search, analyze and select the necessary information, its processing, preservation and transmission.

The existing positive pedagogical experience of bilingual education suggests that its use in the teaching of professional mathematical disciplines is an important aspect of the formation of the informational competence of foreign students.

The purpose of the article is to substantiate the expediency of introducing bilingual education in the formation of the informational competence of Turkmen students in pedagogical universities; description of methodological peculiarities of the use of the mathematical terminology dictionary (glossary) as a form of bilingualism in the educational process.

In teaching mathematical disciplines of foreign students the formation of information competence is based on the use of a certain set of principles and is ensured by the introduction into the practice of special program-pedagogical developments.

One such methodological tool is a glossary of mathematical disciplines, in which the language of symbols and in Russian provides necessary mathematical symbols with the transcription of its reading, the basic notions and their definitions, important mathematical statements in accordance with the sections and the work program of discipline. Its use contributes to the formation of the necessary terminology base for each student, prompts foreign students to seek learning information and allows them to set their own learning pace.

Generalization of the results of scientific-pedagogical research confirms the growth of the general level of formation of information competence of Turkmen students.

Key words: information competence, foreign students, bilingual education, glossary, mathematical disciplines. 